Article

\title{
Optimization of Glutamine Peptide Production from Soybean Meal and Analysis of Molecular Weight Distribution of Hydrolysates
}

\author{
Yanli Xie ${ }^{1{ }^{1} *}$, Xinhong Liang ${ }^{2}$, Min Wei ${ }^{1}$, Wenhong Zhao ${ }^{1}$, Baoshan He ${ }^{1}$, Qiyu Lu ${ }^{1}$, \\ Quangong Huo ${ }^{1}$ and Chengye Ma ${ }^{1}$
}

1 School of Food Science and Technology, Henan University of Technology, Zhengzhou 450001, China; E-Mails: wei_min80@163.com (M.W.); zhwh2008@yahoo.cn (W.Z.); hebaoshan@126.com (B.H.); qiyulu7120@vip.sina.com (Q.L.); huo_qg@126.com (Q.H.); hnmcy@sina.com (C.M.)

2 School of Food Science and Technology, Henan Institute of Science and Technology, Xinxiang 453003, China; E-Mail: liangxinhong2005@163.com

* Author to whom correspondence should be addressed; E-Mail: yanlixie@yahoo.cn; Tel./Fax: +86-371-6775-8022.

Received: 5 May 2012; in revised form: 5 June 2012 / Accepted: 8 June 2012 / Published: 18 June 2012

\begin{abstract}
The process parameters of enzymatic hydrolysis and molecular weight distribution of glutamine (Gln) peptides from soybean meal were investigated. The Protamex ${ }^{\circledR}$ hydrolysis $\mathrm{pH}$ of 6.10 , temperature of $56.78^{\circ} \mathrm{C}$, enzyme to substrate ratio (E/S) of 1.90 and hydrolysis time of $10.72 \mathrm{~h}$ were found to be the optimal conditions by response surface methodology (RSM) for a maximal degree of hydrolysis (DH) value of $16.63 \%$ and Gln peptides content at $5.95 \mathrm{mmol} / \mathrm{L}$. The soybean meal was hydrolyzed by a combination of Protamex ${ }^{\circledR}$ and trypsinase so that $\mathrm{DH}$ and Gln peptides would reach $22.02 \%$ and $6.05 \mathrm{mmol} / \mathrm{mL}$, respectively. The results of size exclusion chromatography indicated that the relative proportion of the molecular weight $<1000 \mathrm{Da}$ fraction increased with $\mathrm{DH}$ values from $6.76 \%, 11.13 \%, 17.89 \%$ to $22.02 \%$, most notably the $132-500$ Da fractions of hydrolysates were $42.14 \%, 46.57 \%, 58.44 \%$ and $69.65 \%$. High DH values did not lead to high Gln peptides content of the hydrolysate but to the low molecular weight Gln peptides.
\end{abstract}

Keywords: glutamine peptide; soybean meal; enzymatic hydrolysis; response surface methodology; molecular weight distribution 


\section{Introduction}

Soybean is one of the most important oilseeds in the world. The industrial processing of soybean yields two products, oil and a low-valued defatted soybean meal. Soybean meal protein has shown markedly higher values and is good source of bioactive peptides [1,2]. Glutamine is the most abundant amino acid in the human body, where it plays a number of important physiological roles that fuel the rapid proliferation of cells (fibroblasts, immune and gastrointestinal cells) [3]. The glutamic acid/glutamine content in wheat, corn and soybean meal is $31.90 \%, 20.48 \%$ and $18.82 \%$, respectively [4-6]. Glutamine deficiency may compromise many important cellular protective, immunosuppressive and disease recovery processes that affect patient survival [7]. Prabhu reported that oral supplementation of glutamine or glutamic acid altered the brush border membrane in the intestine to prevent postoperative complications after surgical manipulation [8].

Recent studies suggest that plasma glutamine levels are a useful indicator of immunocompetence and overtraining syndrome and assert that glutamine is a potentially useful dietary supplement for subjects engaging in intensive athletic training [9]. However, the solubility and stability of free glutamine were found to be limited, and it is easily broke down into pyroglutamic acid and ammonia during autoclaving [10], which rules out incorporation into currently available nutritional preparations. Following this, the dipeptide concept with stable, highly soluble synthetic glutamine was investigated to overcome these drawbacks. Peptide-bound glutamine extracted from plant protein by enzymatic hydrolysis has the advantage of good safety in enteral nutrition. Wheat gluten treated with protease was developed to produce a peptide-bound glutamine for enteral nutrition and the oligopeptide fraction enhanced mucosal protein content significantly more effectively in fasting rats when compared to a simulated free amino acid mixture. Additionally, rats showed greater resistance to methotrexate-induced enterocolitis when they were fed the oligopeptide fraction rather than a simulated free amino acid mixture [11]. Dietary supplemented glutamine and soybean peptides have important effects on the structure of the kidney filtration barrier and the content of total protein, albumin and 2-microglobulin in the urine of an over-training group [12]. Plant protein hydrolysates were mainly used as protein ingredients or supplements in food or as ingredients in special formulations for clinical nutrition [13]. Molecular weight plays an important role in the functional and biological properties of peptides [14], and therefore, it is essential to determine molecular weight distribution of protein hydrolysates and the process parameters that control it. This research aimed to optimize glutamine peptide production from soybean meal and to analyze the molecular weight distribution of hydrolysates, since they promise better utilization of soybean by-products from extracting oil.

\section{Results and Discussion}

\subsection{Statistical Analysis and Model Fit of Hydrolysis Process}

The central composite design of the four independent variables $(\mathrm{pH}$, temperature, $\mathrm{E} / \mathrm{S}$ and reaction time) and the responses (DH value and Gln content) are shown in Table 1. Multiple regression analysis was performed on the experimental data to obtain the predictive model using the following second-order polynomial Equations $(1,2)$ : 
$\mathrm{R}_{1}: \mathrm{DH}=15.257-0.795 \mathrm{X}_{1}+0.118 \mathrm{X}_{2}+0.651 \mathrm{X}_{3}+0.379 \mathrm{X}_{4}-0.589 \mathrm{X}_{1} \mathrm{X}_{2}+0.197 \mathrm{X}_{1} \mathrm{X}_{3}-0.048$

$\mathrm{X}_{1} \mathrm{X}_{4}-0.227 \mathrm{X}_{2} \mathrm{X}_{3}-0.092 \mathrm{X}_{2} \mathrm{X}_{4}-0.013 \mathrm{X}_{3} \mathrm{X}_{4}-0.313 \mathrm{X}_{1}^{2}-0.359 \mathrm{X}_{2}^{2}-0.200 \mathrm{X}_{3}^{2}-0.139 \mathrm{X}_{4}^{2}$

$\mathrm{R}_{2}$ :Glncontent $=5.647-0.075 \mathrm{X}_{1}-0.006 \mathrm{X}_{2}+0.066 \mathrm{X}_{3}+0.085 \mathrm{X}_{4}+0.002 \mathrm{X}_{1} \mathrm{X}_{2}+0.111 \mathrm{X}_{1} \mathrm{X}_{3}-$ $0.053 \mathrm{X}_{1} \mathrm{X}_{4}+0.004 \mathrm{X}_{2} \mathrm{X}_{3}-0.004 \mathrm{X}_{2} \mathrm{X}_{4}+0.079 \mathrm{X}_{3} \mathrm{X}_{4}-0.062 \mathrm{X}_{1}^{2}-0.019 \mathrm{X}_{2}^{2}+0.001 \mathrm{X}_{3}^{2}+0.026 \mathrm{X}_{4}^{2}$

Table 1. Four-factor central composite design and values of responses. Independent variables: Temperature $\left(\mathrm{X}_{1}\right), \mathrm{pH}\left(\mathrm{X}_{2}\right), \mathrm{E} / \mathrm{S}\left(\mathrm{X}_{3}\right)$ and reaction time $\left(\mathrm{X}_{4}\right)$.

\begin{tabular}{|c|c|c|c|c|c|c|}
\hline & \multicolumn{4}{|c|}{ Independent Variable } & \multicolumn{2}{|c|}{ Response } \\
\hline & $\mathbf{X}_{1}$ & $\mathrm{X}_{2} /{ }^{\circ} \mathrm{C}$ & $\mathrm{X}_{\mathbf{3}} / \%$ & $\mathbf{X}_{\mathbf{4}} / \mathbf{h}$ & $Y_{1}: D H, \%$ & $\mathrm{Y}_{2}: \mathrm{Gln} \mathrm{mmol} / \mathrm{L}$ \\
\hline 1 & -1 & 1 & 1 & -1 & $15.83 \pm 0.18$ & $5.32 \pm 0.06$ \\
\hline 2 & 1 & -1 & -1 & 1 & $13.34 \pm 0.20$ & $5.23 \pm 0.15$ \\
\hline 3 & -1 & -1 & -1 & 1 & $14.23 \pm 0.26$ & $5.72 \pm 0.14$ \\
\hline 4 & -1 & -1 & 1 & -1 & $14.52 \pm 0.14$ & $5.31 \pm 0.06$ \\
\hline 5 & -2 & 0 & 0 & 0 & $15.32 \pm 0.13$ & $5.54 \pm 0.16$ \\
\hline 6 & 0 & 0 & 0 & 0 & $15.41 \pm 0.06$ & $5.49 \pm 0.21$ \\
\hline 7 & 0 & 2 & 0 & 0 & $13.94 \pm 0.14$ & $5.69 \pm 0.06$ \\
\hline 8 & -1 & -1 & -1 & -1 & $13.17 \pm 0.25$ & $5.64 \pm 0.04$ \\
\hline 9 & 0 & 0 & -2 & 0 & $12.91 \pm 0.02$ & $5.67 \pm 0.08$ \\
\hline 10 & 1 & 1 & 1 & 1 & $14.01 \pm 0.16$ & $5.66 \pm 0.11$ \\
\hline 11 & -1 & 1 & -1 & 1 & $16.08 \pm 0.23$ & $5.73 \pm 0.07$ \\
\hline 12 & 0 & 0 & 2 & 0 & $15.75 \pm 0.09$ & $5.96 \pm 0.10$ \\
\hline 13 & 0 & 0 & 0 & 0 & $15.27 \pm 0.30$ & $5.78 \pm 0.14$ \\
\hline 14 & 0 & 0 & 0 & 0 & $15.21 \pm 0.13$ & $5.59 \pm 0.08$ \\
\hline 15 & 1 & 1 & -1 & -1 & $12.03 \pm 0.28$ & $5.21 \pm 0.04$ \\
\hline 16 & 1 & 1 & -1 & 1 & $12.62 \pm 0.12$ & $5.22 \pm 0.12$ \\
\hline 17 & 0 & 0 & 0 & 0 & $15.01 \pm 0.10$ & $5.54 \pm 0.19$ \\
\hline 18 & -1 & 1 & -1 & -1 & $15.39 \pm 0.23$ & $5.63 \pm 0.11$ \\
\hline 19 & 0 & 0 & 0 & 2 & $15.38 \pm 0.22$ & $6.01 \pm 0.18$ \\
\hline 20 & 0 & 0 & 0 & -2 & $13.77 \pm 0.11$ & $5.82 \pm 0.15$ \\
\hline 21 & 1 & -1 & 1 & -1 & $14.61 \pm 0.09$ & $5.44 \pm 0.06$ \\
\hline 22 & -1 & -1 & 1 & 1 & $15.83 \pm 0.06$ & $5.86 \pm 0.13$ \\
\hline 23 & -1 & 1 & 1 & 1 & $16.09 \pm 0.19$ & $5.85 \pm 0.05$ \\
\hline 24 & 1 & 1 & 1 & -1 & $13.35 \pm 0.21$ & $5.50 \pm 0.11$ \\
\hline 25 & 0 & 0 & 0 & 0 & $15.52 \pm 0.19$ & $5.65 \pm 0.09$ \\
\hline 26 & 0 & -2 & 0 & 0 & $13.45 \pm 0.22$ & $5.78 \pm 0.11$ \\
\hline 27 & 1 & -1 & 1 & 1 & $15.21 \pm 0.13$ & $5.67 \pm 0.08$ \\
\hline 28 & 1 & -1 & -1 & -1 & $12.64 \pm 0.17$ & $5.22 \pm 0.12$ \\
\hline 29 & 2 & 0 & 0 & 0 & $12.44 \pm 0.22$ & $5.59 \pm 0.21$ \\
\hline 30 & 0 & 0 & 0 & 0 & $15.12 \pm 0.21$ & $5.83 \pm 0.15$ \\
\hline
\end{tabular}

Significance of the coefficients to DH was determined using the F-test and p-value for the influence of $\mathrm{pH}$, temperature, E/S and reaction time (Table 2). The ANOVA of the quadratic regression model shows high significance for the model $(p<0.0001)$ and it is therefore suitable for monitoring optimization. The effect of $\mathrm{pH}, \mathrm{E} / \mathrm{S}$ and reaction time exerted highly significant effect on $\mathrm{DH}$ values $(p<0.0001)$, and hydrolysis temperature was also significant $(p<0.05)$. Moreover, the quadratic term 
of $\mathrm{pH}\left(\mathrm{X}_{1}^{2}\right)$, temperature $\left(\mathrm{X}_{2}^{2}\right), \mathrm{E} / \mathrm{S}\left(\mathrm{X}_{3}^{2}\right)$ and reaction time $\left(\mathrm{X}_{4}^{2}\right)$ also showed highly significant effects on DH values $(p<0.001)$. In addition, two-way interaction for parameters was significant for $\mathrm{pH}$ and temperature $(p<0.0001), \mathrm{pH}$ and $\mathrm{E} / \mathrm{S}$, and temperature and $\mathrm{E} / \mathrm{S}(p<0.001)$, and not significant for interaction between $\mathrm{pH}$ and reaction time, temperature and reaction time or $\mathrm{E} / \mathrm{S}$ and reaction time $(p>0.05)$. The statistical analysis for the model (Table 2) showed the lack of fit was not significant for pure error $(p>0.05)$. The coefficient of determination $\mathrm{R}^{2}$ was 0.9818 and $\operatorname{Adj} R^{2}$ was 0.9649 , i.e., the model fit could explain $96.49 \%$ of total variability within the range of values studied. In further analysis, each observed value for $\mathrm{DH}\left(\mathrm{Y}_{1}{ }^{\prime}\right)$ was compared with the adequate predicted value $\left(\mathrm{Y}_{1}\right)$ (Figure 1A). All these results imply that the model gives a satisfactory mathematical description of the hydrolysis process Equation (1).

Table 2. Significance of regression coefficients for degree of hydrolysis (DH) and glutamine (Gln) content.

\begin{tabular}{|c|c|c|c|c|c|c|c|c|c|}
\hline \multirow[t]{2}{*}{ Source } & \multicolumn{2}{|c|}{ Sum of Squares } & \multirow{2}{*}{ df } & \multicolumn{2}{|c|}{ Mean Square } & \multicolumn{2}{|l|}{ F-Value } & \multicolumn{2}{|c|}{$p$-Value/Prob $>F$} \\
\hline & DH & Gln & & DH & Gln & DH & Gln & DH & Gln \\
\hline Model & 42.196 & 0.905 & 14 & 3.014 & 0.065 & 57.952 & 1.790 & $<0.0001^{* * * *}$ & $0.1377^{\text {ns }}$ \\
\hline \multicolumn{10}{|l|}{ Linear } \\
\hline $\mathrm{X}_{1}$ & 15.185 & 0.137 & 1 & 15.185 & 0.137 & 291.963 & 3.780 & $<0.0001^{* * * *}$ & $0.0709^{\mathrm{ns}}$ \\
\hline $\mathrm{X}_{2}$ & 0.334 & 0.001 & 1 & 0.334 & 0.001 & 6.416 & 0.026 & $0.0230^{*}$ & $0.8741^{\mathrm{ns}}$ \\
\hline $\mathrm{X}_{3}$ & 10.179 & 0.105 & 1 & 10.179 & 0.105 & 195.719 & 2.917 & $<0.0001^{* * * *}$ & $0.1083^{\mathrm{ns}}$ \\
\hline $\mathrm{X}_{4}$ & 3.443 & 0.175 & 1 & 3.443 & 0.175 & 66.198 & 4.849 & $<0.0001^{* * * *}$ & $0.0437^{\text {ns }}$ \\
\hline \multicolumn{10}{|l|}{ Quadratic } \\
\hline $\mathrm{X}_{1}^{2}$ & 2.680 & 0.103 & 1 & 2.680 & 0.103 & 51.537 & 2.840 & $<0.0001^{* * * *}$ & $0.1126^{\mathrm{ns}}$ \\
\hline $\mathrm{X}_{2}^{2}$ & 3.532 & 0.010 & 1 & 3.532 & 0.010 & 67.915 & 0.264 & $<0.0001^{* * * *}$ & $0.6148^{\mathrm{ns}}$ \\
\hline $\mathrm{X}_{3}^{2}$ & 1.098 & 0.000 & 1 & 1.098 & 0.000 & 21.118 & 0.001 & $0.0004^{* * *}$ & $0.9707^{\text {ns }}$ \\
\hline $\mathrm{X}_{4}^{2}$ & 0.529 & 0.019 & 1 & 0.529 & 0.019 & 10.168 & 0.528 & $0.0061^{* * *}$ & $0.4788^{\mathrm{ns}}$ \\
\hline \multicolumn{10}{|l|}{ Interaction } \\
\hline $\mathrm{X}_{1} \mathrm{X}_{2}$ & 5.558 & 0.000 & 1 & 5.558 & 0.000 & 106.864 & 0.002 & $<0.0001^{* * * *}$ & $0.9690^{\mathrm{ns}}$ \\
\hline $\mathrm{X}_{1} \mathrm{X}_{3}$ & 0.620 & 0.196 & 1 & 0.620 & 0.196 & 11.924 & 5.422 & $0.0035^{* *}$ & $0.0343^{\mathrm{ns}}$ \\
\hline $\mathrm{X}_{1} \mathrm{X}_{4}$ & 0.037 & 0.045 & 1 & 0.037 & 0.045 & 0.7125 & 1.251 & $0.4119^{\mathrm{ns}}$ & $0.2810^{\mathrm{ns}}$ \\
\hline $\mathrm{X}_{2} \mathrm{X}_{3}$ & 0.824 & 0.000 & 1 & 0.824 & 0.000 & 15.835 & 0.008 & $0.0012^{* *}$ & $0.9278^{\text {ns }}$ \\
\hline $\mathrm{X}_{2} \mathrm{X}_{4}$ & 0.135 & 0.000 & 1 & 0.135 & 0.000 & 2.597 & 0.008 & $0.1279^{\mathrm{ns}}$ & $0.9278^{\mathrm{ns}}$ \\
\hline $\mathrm{X}_{3} \mathrm{X}_{4}$ & 0.003 & 0.101 & 1 & 0.003 & 0.101 & 0.053 & 2.792 & $0.8210^{\mathrm{ns}}$ & $0.1155^{\mathrm{ns}}$ \\
\hline \multicolumn{10}{|c|}{ Statistic analysis for the model } \\
\hline Residual & 0.780 & & 15 & 0.052 & 0.036 & & & & \\
\hline Lack of Fit & 0.605 & & 10 & 0.061 & 0.045 & 1.732 & 2.491 & $0.2829^{\mathrm{ns}}$ & $0.1627^{\mathrm{ns}}$ \\
\hline Pure Error & 0.175 & & 5 & 0.035 & 0.018 & & & & \\
\hline Cor Total & 42.976 & & 29 & & & & & & \\
\hline
\end{tabular}


Figure 1. Predicted response vs. actual value for degree of hydrolysis (DH) and glutamine (Gln) content.
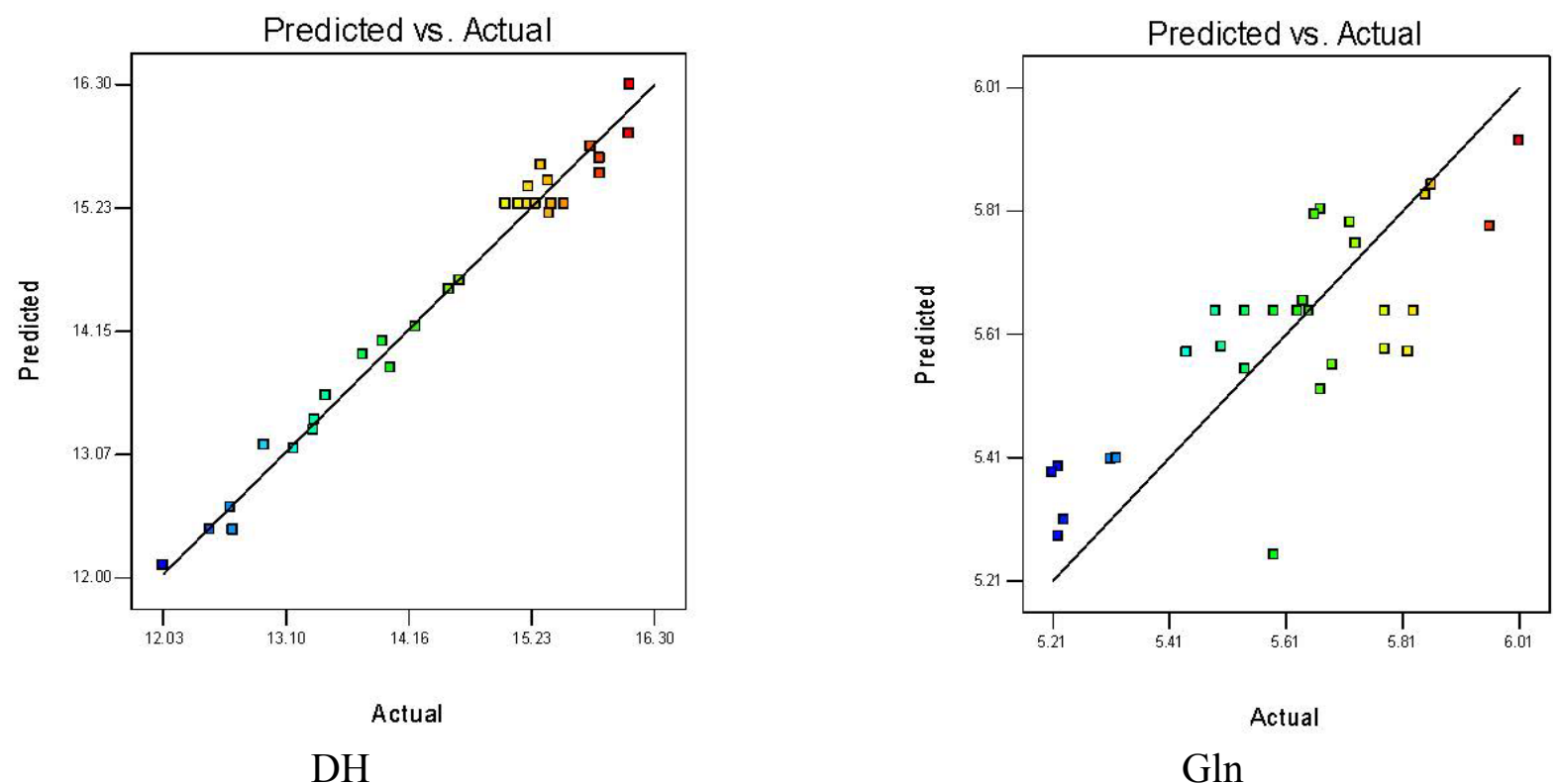

The ANOVA of the quadratic regression model gives no significance for the Gln content model $(p>0.05)$ (Table 2). These variables had no significant effect on response $(p>0.05)$. Given $R^{2}$ at 0.6255 and $\operatorname{Adj} R^{2}$ at 0.2760 , the model gave a poor fit with the experimental data and a disappointing mathematical description for Gln yield. Figure 1B shows that the actual gap between Gln response $\left(\mathrm{Y}_{2}\right)$ values and the predicted values $\left(\mathrm{Y}_{2}{ }^{\prime}\right)$. In general, peptides activity is affected considerably by the $\mathrm{DH}$ of the protein substrate(s), and the independent variables ( $\mathrm{pH}$, temperature, $\mathrm{E} / \mathrm{S}$ and reaction time) have an effect on the DH. The high peptides activity was not only a result of extensive hydrolysis, but also due to some intrinsic properties of the protein substrate(s) or specificity of the enzyme(s) [15]. The Gln peptides content was not observed to change obviously with increasing DH, so the Gln content was not appropriate as an objective function. The molecular weight of peptides greatly affects their functional and biological properties and the low molecular weight of Gln peptide results in faster absorption inside the body, so the activity of peptide segments were affected by the DH value to some extent $[2,14]$.

\subsection{Effect of pH, Temperature, E/S Ratio and Reaction Time on Hydrolysis}

Response surface methodology (RSM) is an effective, widely accepted method of solving multivariate problems to properly predict the values of the response variables in many types of research [16]. It generates 3D response surface and 2D contour plots to show the interrelationships between two tested variables and the relationship between responses and experimental levels of each variable. The optimal values of the selected variables were obtained by regression analysis on Design-Expert 7.0. Two variables within the experimental range are depicted with the third variable kept constant at zero. Different shapes of contour plots indicate different interactions between two variables and circular plots of response surfaces suggest negligible interaction between corresponding variables while elliptical or saddle-shaped plots highlight significant interaction between 
corresponding variables. For saddle contour plots, the optimum values are obtained at the point of intersection of lines formed by joining the locus [17].

Figure 2. Response surface plots and contour plots for the interactive effects of variables on the $\mathrm{DH}$ value. (a) $\mathrm{pH}$ and temperature; (b) $\mathrm{pH}$ and $\mathrm{E} / \mathrm{S}$ ratio; (c) $\mathrm{pH}$ and reaction time; (d) temperature and $\mathrm{E} / \mathrm{S}$ ratio; (e) temperature and reaction time; (f) $\mathrm{E} / \mathrm{S}$ ratio and reaction time.

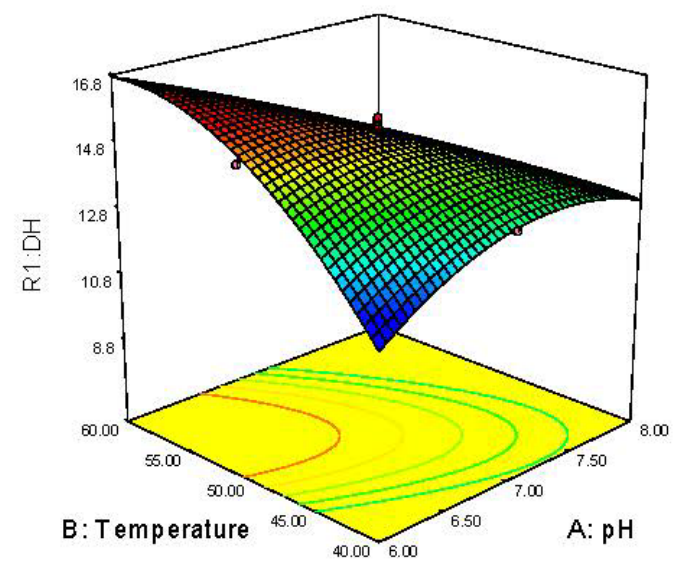

(a)

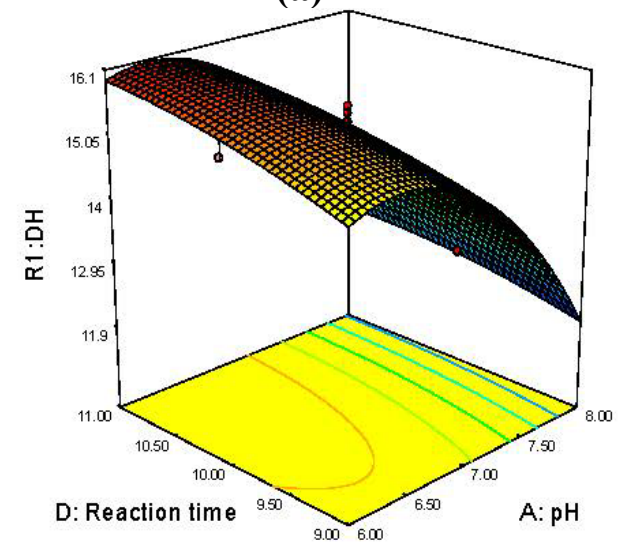

(c)

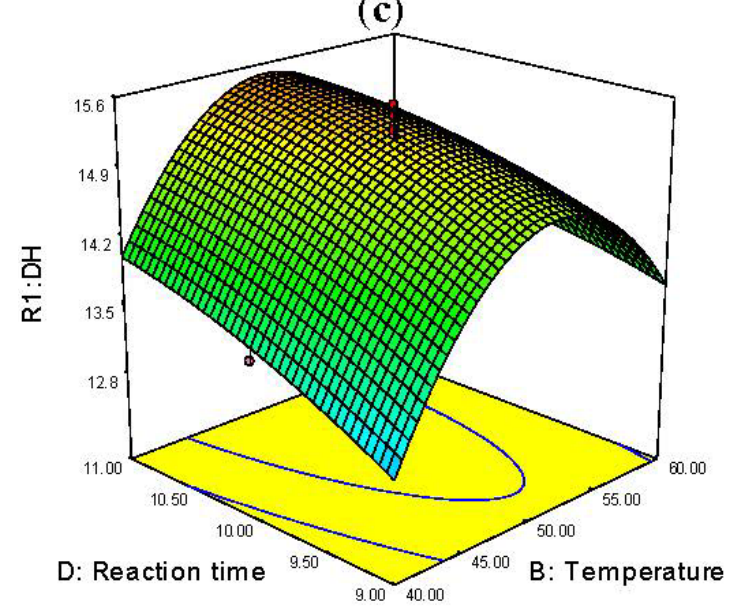

(e)

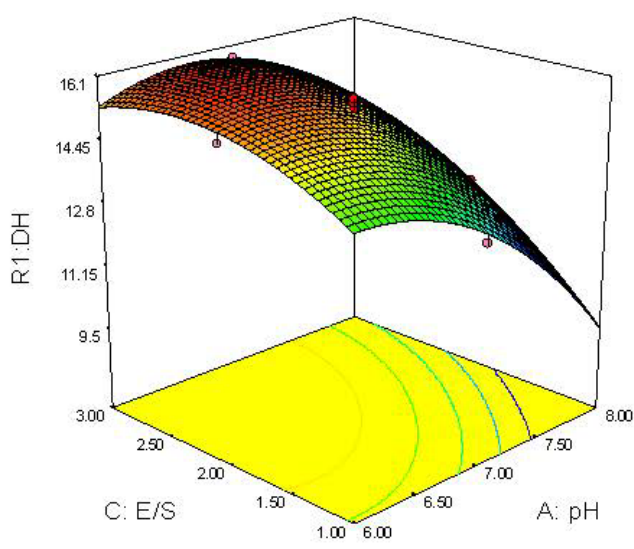

(b)

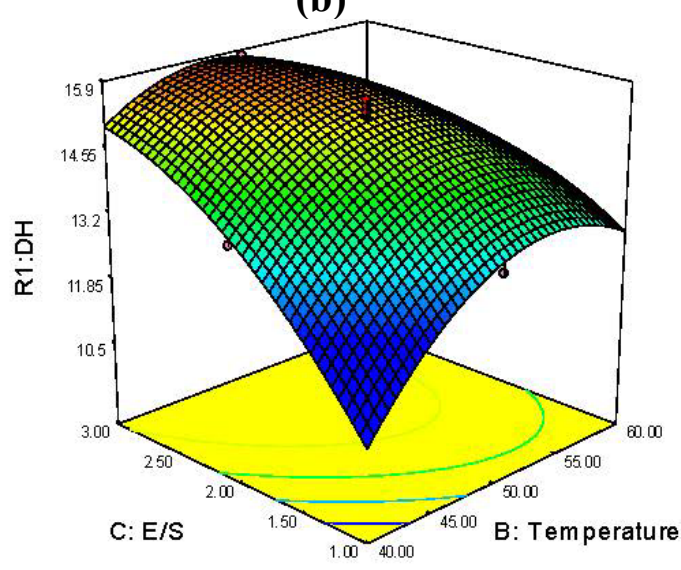

(d)

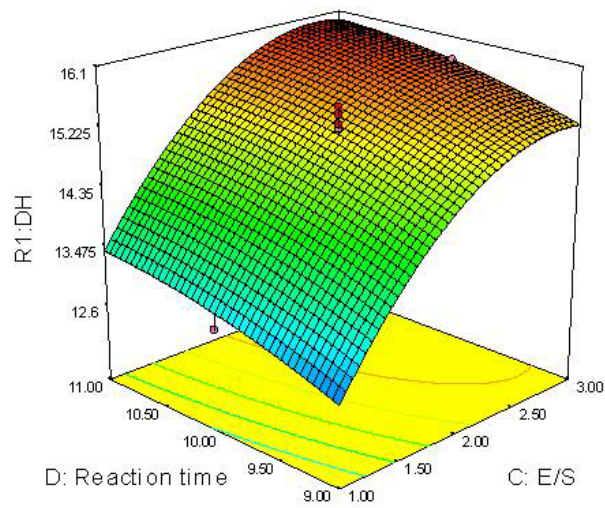

(f)

The 3D surface and 2D contour plots (Figure 2) were drawn to illustrate the principal interactive effects of the independent variables on the dependent DH. Figure 2A shows the 3D surface and 
contour plots of the effect of $\mathrm{pH}$ and temperature on $\mathrm{DH}$. Visibly, $\mathrm{DH}$ increased with $\mathrm{pH}$ until a peak at about 7.0. There was an ellipse in the contour plot for $\mathrm{DH}$ expressed as a function of $\mathrm{pH}$ and temperature, which indicates the significance of interactions between $\mathrm{pH}$ and temperature (Figure 2A). In the E/S range of $1.0 \%-3.0 \%$, considered as the economical usage range of the enzyme, the $\mathrm{DH}$ value increased with the E/S and peaked at about $2.5 \%$ (Figure 2B). The saddle contour plots in Figure $2 \mathrm{~B}$ plainly show that interactions between $\mathrm{pH}$ and $\mathrm{E} / \mathrm{S}$ ratio also reached their optimum levels. DH barely increased with reaction time from 9 to $11 \mathrm{~h}$ as seen in Figure 2C. Low $\mathrm{pH}$ favored the higher $\mathrm{DH}$ value, which dropped linearly as $\mathrm{pH}$ increased from 6.3 to 8.0. The circular contour plots of response surfaces suggest that the interaction of $\mathrm{pH}$ and reaction time is negligible with the corresponding variables (Figure 2C). Figure 2D shows that DH increased gradually as temperature rose in the medium until gradually peaking at about $49^{\circ} \mathrm{C}$. $\mathrm{DH}$ also tended to increase along with E/S. The elliptical contour plots indicate the significance of the interaction between temperature and $\mathrm{E} / \mathrm{S}$ (Figure 2D). As shown in Figure 2E, DH increased until the temperature reached an optimal peak at about $50{ }^{\circ} \mathrm{C}$. In terms of reaction time, DH slowly increased as hydrolysis was prolonged from 9 to $11 \mathrm{~h}$. Circular contour plots, which signal non-significance for the interaction between temperature and reaction time, were clearly shown. Further, Figure $2 \mathrm{~F}$ shows that $\mathrm{DH}$ increased along with E/S from $1 \%$ up to $2.8 \%$ and peaked at about $2.8 \%$. Likewise, $\mathrm{DH}$ rose slightly as reaction time increased from 9 to $11 \mathrm{~h}$. The plot in Figure $2 \mathrm{~F}$ for $\mathrm{DH}$ as a function of $\mathrm{E} / \mathrm{S}$ and reaction time was circular, thereby illustrating that this interaction was not significant.

\subsection{Optimization and Validation of the Experimental Design}

Optimal conditions of the variables were $\mathrm{pH} 6.10,56.78^{\circ} \mathrm{C}, \mathrm{E} / \mathrm{S} 1.90$ and a reaction time of $10.72 \mathrm{~h}$ as determined on Design-Expert, under which the predicted DH value was $16.78 \%$. Applying these conditions, the experiment scored $16.63 \%$ while Gln content was $5.95 \mathrm{mmol} / \mathrm{L}$. These two percentages are close enough to validate the model. The optimum parameters of trypsinase previously reported by our laboratory were: $\mathrm{pH} 7.83,50{ }^{\circ} \mathrm{C}, \mathrm{E} / \mathrm{S} 4.5$ and hydrolysis time $3.7 \mathrm{~h}$ such that the $\mathrm{DH}$ value and Gln could reach $12.79 \%$ with glutamine content at $5.92 \mathrm{mmol} / \mathrm{mL}$ [18]. The defatted soybean meal was hydrolyzed by trypsinase and Protamex ${ }^{\circledR}$ at their respective optimal parameters such that DH and Gln reached $22.02 \%$ and $6.05 \mathrm{mmol} / \mathrm{mL}$, respectively, so the soy meal was well hydrolyzed. The diversification of hydrolysis degree and molecular weight distribution were investigated during the process of defatted soybean meal hydrolysis.

\subsection{Effect of the Diversification of Hydrolysis Degree on the Molecular Weight Distribution}

The molecular weight distribution profiles of the defatted soybean meal hydrolysates obtained with trypsinase and Protamex ${ }^{\circledR}$ are presented in Figure 3. The molecular weight distribution of defatted soybean meal hydrolysates ranged from 100 to $10,000 \mathrm{Da}$ and most soybean meal peptides were smaller than $1000 \mathrm{Da}$ (Figure 3). According to their molecular weight ranges: $>10,000,10,000-5000$, 5000-2000, 2000-1000, 1000-500, 500-132 and <132, the seven absorption peaks in the chromatogram were marked out. Comparing the relative areas, there could be some differences in interpretation of the areas due to the lack of the molar extinction coefficients required to do an accurate quantitation. The surface area of the $>1000 \mathrm{Da}$ group decreased while that of $<1000 \mathrm{Da}$ groups 
increased using four DH values ranging from $6.76 \%, 11.13 \%, 17.89 \%$ and $22.02 \%$, respectively. The relative proportions of molecular weight $<1000 \mathrm{Da}$ fraction of the hydrolysates were $71.96 \%, 74.55 \%$, $86.52 \%$ and $92.37 \%$ at $\mathrm{DH}$ values of $6.76 \%, 11.13 \%, 17.89 \%$ and $22.02 \%$, respectively. The relative proportions for $132-500 \mathrm{Da}$ fraction of hydrolysates were $42.14 \%, 46.57 \%, 58.44 \%$ and $69.65 \%$ with $\mathrm{DH}$ values of $6.76 \%, 11.13 \%, 17.89 \%$ and $22.02 \%$, respectively. The results indicate that defatted soybean meal hydrolysates contained many short peptides, greatly due to trypsinase and Protamex ${ }^{\circledR}$. The functional and biological properties of protein hydrolysates correlated with the degree of hydrolysis and molecular weight [14,19].

Figure 3. Effect of $\mathrm{DH}$ on the molecular weight distribution of hydrolysates. (A): $\mathrm{DH}=6.76 \% ;(\mathbf{B}): \mathrm{DH}=11.13 \% ;(\mathbf{C}): \mathrm{DH}=17.98 \% ;(\mathbf{D}): \mathrm{DH}=22.02 \%$.
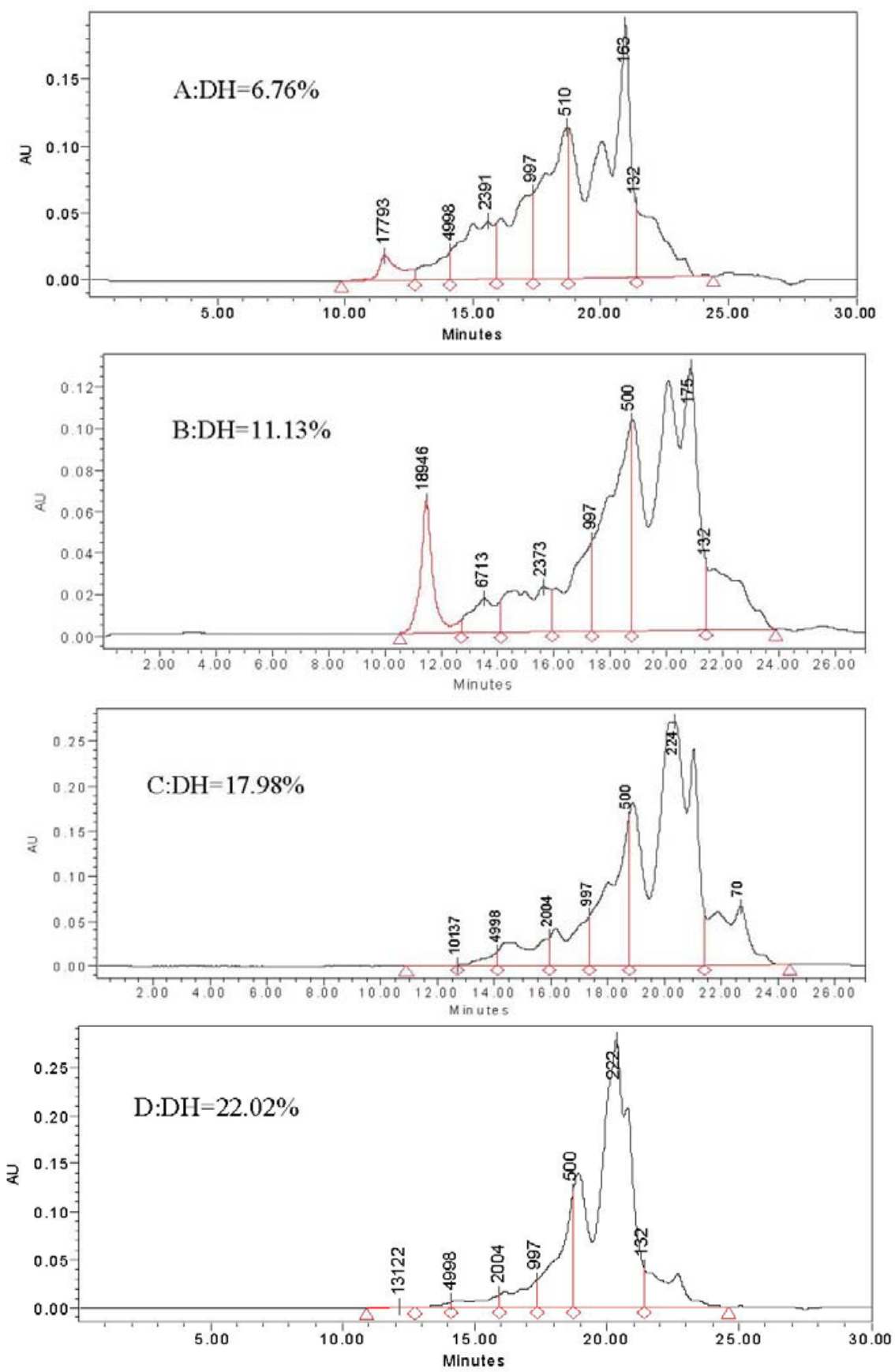


\section{Experimental Section}

\subsection{Materials}

Defatted soybean meal was supplied by Xuchang Bangdi Protein Industry Co., Ltd. (Henan, China). Protamex ${ }^{\circledR}(40,000 \mathrm{U} / \mathrm{g})$ and trypsinase $(48,000 \mathrm{U} / \mathrm{g})$ commercial enzymes were kindly donated by Novozyme (Beijing, China). L-Gly-Gln standards were purchased from Sigma Chemical Co. (St. Louis, MO, USA). All other reagents used were of analytical grade. [Bis(trifluoroacetoxy)iodo]benzene was purchased from Shanghai Yurlic Chemical S\&T Co.Ltd (Shanghai, China). Isothiocyanic acid phenyl ester was purchased from Acros Organics (Pittsburgh, USA). Acetonitrile (chromatographically) was purchased from Tianjing Kemiou chemreagen Co.Ltd (Tianjing, China). Ethylic acid, natrium aceticum, pyridine, triethylamine, trifluoroacetic acid (TFA) and formaldehyde were of analytical-grade.

\subsection{Enzymatic Hydrolysis}

The defatted soybean meal concentration was fixed at $12 \%(\mathrm{w} / \mathrm{v})$ and hydrolyzed with Protamex ${ }^{\circledR}$ according to the hydrolysis conditions defined by the experimental design. Hydrolysis $\mathrm{pH}$ was maintained at the desired value by continuous addition of $0.1 \mathrm{~N} \mathrm{NaOH}$ and $0.1 \mathrm{~N} \mathrm{HCl}$. After the required digestion time, the reaction was stopped by heating the solution to $80{ }^{\circ} \mathrm{C}$ for 20 min to deactivate the enzyme. DH and Gln content were determined from the supernatant after centrifugation at $4000 \times \mathrm{g}$ for $15 \mathrm{~min}$ [20].

\subsection{Determination of the Degree of Hydrolysis}

DH was the percentage of cleaved peptide bonds $(h)$ out of total number of such bonds in the substrate $\left(h_{\text {tot }}\right)$ and was calculated from the amount of base consumed as given below (Equation (3)) [2,21]:

$$
\mathrm{DH} \%=\frac{h \times 100}{h_{\text {tot }}}=\frac{B \times N_{\mathrm{b}} \times 100}{\alpha \times M_{\mathrm{p}} \times h_{\text {tot }}}
$$

where $B$ is base consumption in $\mathrm{mL} ; N_{\mathrm{b}}$ is normality of the base; $\alpha$ is average degree of dissociation of the $\alpha-\mathrm{NH}_{2}$ groups; $M_{\mathrm{p}}$ is mass of protein $(N \times 6.25)$ in $\mathrm{g} ; h$ is the hydrolysis equivalents in meqv/g protein and $h_{\text {tot }}$ is total number of peptide bonds in the protein substrate $(7.75 \mathrm{meqv} / \mathrm{g}$ soy protein).

\subsection{Quantitative Analysis of Glutamine in Soybean Meal Hydrolysates}

Conversion of glutamine residues into diaminobutyric acid (DABA) was performed by adding $100 \mu \mathrm{L}$ bis-1,1-trifluoroacetoxy-iodobenzene (BTI) into acetonitrile $(10 \mathrm{mg} / \mathrm{mL})$, and $25 \mu \mathrm{L}$ aqueous pyridine $(50 \mu \mathrm{mol} / \mathrm{mL})$ was added into $100 \mu \mathrm{L}$ hydrolysis protein solution and incubated at $50{ }^{\circ} \mathrm{C}$ for $20 \mathrm{~h}$. This prehydrolytic reaction was generated for glutamine residues with BTI and converted glutamine to the corresponding diaminobutyric acid (DABA) and was then dried immediately by vacuum.

Acid hydrolysis was performed by adding $200 \mu \mathrm{L}$ of $6 \mathrm{M} \mathrm{HCl}$ into $200 \mu \mathrm{L}$ DABA sample. The obtained solutions were purged with nitrogen gas for $2 \mathrm{~min}$, then hydrolysis was carried out at $110^{\circ} \mathrm{C}$ for $23 \mathrm{~h}$. The acid digested samples were freeze dried. 
HPLC analysis was performed on a Waters 2695 Alliance System (Waters Corporation, Millipore, Milford, MA, USA), UV detector and a Waters symmetry column $\mathrm{C} 18$ oven set to $40{ }^{\circ} \mathrm{C}$, flow rate $0.3 \mathrm{~mL} / \mathrm{min}$ and injection volume $5 \mu \mathrm{L}$. The freeze dried acid digested samples was dissolved in mobile phase and loaded on a $2.1 \times 50 \mathrm{~mm} \mathrm{C18}$ column (Waters Corporation, Millipore, Milford, MA, USA), then separated and eluted using an aqueous sodium acetate-acetonitrile gradient and detected at $254 \mathrm{~nm}$ [22].

\subsection{Size Exclusion Chromatography}

Molecular weight distribution of peptides in the different hydrolysates was determined by gel permeation chromatography (TSKgel 2000 SWXL $300 \mathrm{~mm} \times 7.8 \mathrm{~mm}$ ) as described by Dong [23]. The sample was dissolved in mobile phase and filtered by micropore membrane and the injection volume was $20 \mu \mathrm{L}$. The liquid chromatographic system consisted of a Waters 600 automated gradient controller pump (Waters Corporation, Millipore, Milford, MA, USA) and a 2487 UV detector at $220 \mathrm{~nm}$. The mobile phase_isocratic elution consisted of $0.1 \%(\mathrm{v} / \mathrm{v})$ TFA and acetonitrile $(55: 45)$. The flow rate was $0.5 \mathrm{~mL} / \mathrm{min}$. System control and data processing was performed using Empower GPC software (Version 2.0, Waters Corporation, Millipore: Milford, MA, USA). A molecular weight calibration curve was prepared from the elution time of the peak volume using five standards: Cytochrome C (12,500 Da), aprotinin (6500 Da), bacitracin (1450 Da), Gly-Gly-Tyr-Arg (451 Da) and Gly-Gly-Gly $(189 \mathrm{Da})$. A relationship between the retention time and the log of the molecular mass of peptides used as standards was established. In the different hydrolysates, peptides were sorted in 5 fractions covering the ranges of 0-500 Da (fraction V), 500-1000 Da (fraction IV), 1000-2000 Da (fraction III), 2000-5000 Da (fraction II) and above $5000 \mathrm{Da}$ (fraction I). The relative areas of each fraction were given in percent of the total area.

\subsection{Experiment Design}

Temperature $\left(\mathrm{X}_{1}\right), \mathrm{pH}\left(\mathrm{X}_{2}\right), \mathrm{E} / \mathrm{S}\left(\mathrm{X}_{3}\right)$ and reaction time $\left(\mathrm{X}_{4}\right)$ were chosen as independent variables and optimized using a central composite rotatable design (CCRD) [13]. Four key independent variables at five levels were retained and individually coded as $-2,-1,0,+1,+2$ (Table 3 ). The parameters and their ranges were chosen on the basis of the preliminary experimentation data not shown. All experiments were done in quadruplicate, results were averaged and are presented as $\mathrm{Y}_{1}$ and $\mathrm{Y}_{2}$ for $\mathrm{DH}$ and Gln, respectively. The behaviour of the system is explained by the following Equation (4):

$$
y=\beta_{0}+\sum_{i=1}^{3} \beta_{i} x_{i}+\sum_{i=1}^{3} \beta_{i i} x_{i}^{2}+\sum_{i=1}^{2} \sum_{j=i+1}^{3} \beta_{i i} x_{i} x_{j}
$$

where $\mathrm{y}$ is the dependent variable ( $\mathrm{DH}$ value and Gln content); $\beta_{0}$ is a constant; $\beta_{i}, \beta_{i i}$ and $\beta_{i j}$ are coefficients estimated by the model; and $x_{i}$, and $x_{j}$ are levels of the independent variables. They represent the linear, quadratic and cross product effects of the $\mathrm{X}_{1}, \mathrm{X}_{2}, \mathrm{X}_{3}$ and $\mathrm{X}_{4}$ factors respectively. 
Table 3. Coded and uncoded setting of the process parameters.

\begin{tabular}{lcccccc}
\hline Process Parameter & Code & \multicolumn{7}{c}{ Level } \\
\cline { 3 - 7 } & & $\mathbf{- 2}$ & $\mathbf{- 1}$ & $\mathbf{0}$ & $\mathbf{+ 1}$ & $+\mathbf{2}$ \\
\hline $\mathrm{pH}$ & $\mathrm{X}_{1}$ & 6.0 & 6.5 & 7.0 & 7.5 & 8.0 \\
Temperature $/{ }^{\circ} \mathrm{C}$ & $\mathrm{X}_{2}$ & 40 & 45 & 50 & 55 & 60 \\
E/S (\%) & $\mathrm{X}_{3}$ & 1 & 1.5 & 2 & 2.5 & 3.0 \\
Reaction time (h) & $\mathrm{X}_{4}$ & 8 & 9 & 10 & 11 & 12 \\
\hline
\end{tabular}

\subsection{Statistical Analysis}

Design Expert 7.0 statistical software (Stat-Ease Inc., Minneapolis, MO, USA) was used to analyze the experiment design. One-way variance analysis (ANOVA) $(p<0.05)$ was conducted for the response values obtained by the RSM model.

\section{Conclusions}

The effects of four independent variables on the production of glutamine peptides from soybean meal were determined using response surface methodology as a predictive tool. The parameters of the DH model were estimated by multiple linear regression, obtaining a good fit with the experimental data, given that the Adj $R^{2}$ was 0.9649 . With a combination of Protamex ${ }^{\circledR}$ and trypsinase, DH values and Gln peptides content were $22.02 \%$ and $6.05 \mathrm{mmol} / \mathrm{mL}$, respectively. At $\mathrm{DH}$ values of $6.76 \%$, $11.13 \%, 17.89 \%$ and $22.02 \%$, the relative proportions of molecular weight $<1000 \mathrm{Da}$ fraction of hydrolysates were $71.96 \%, 74.55 \%, 86.52 \%$ and $92.37 \%$; more notably the $132-500$ Da fractions were $42.14 \%, 46.57 \%, 58.44 \%$ and $69.65 \%$. The hydrolysates of defatted soybean meal contained many short peptides and were greatly degraded by trypsinase and Protamex ${ }^{\circledR}$.

\section{Acknowledgments}

This work was financially supported by Foundation for University Youth Key Teachers from Henan Province (No. 2010GGJS-085) and Major Project of Science and Technology Development from Henan Province of China (No. 122102110032).

\section{References}

1. Hojilla-Evangelista, M.P.; Sessa, D.J.; Mohamed, A. Functional properties of soybean and lupin protein concentrates produced by ultrafiltration-diafiltration. J. Am. Oil. Chem. Soc. 2004, 81, $1153-1157$.

2. Kong, X.Z.; Guo, M.M.; Hua, Y.F.; Cao, D.; Zhang, C.M. Enzymatic preparation of immunomodulating hydrolysates from soy proteins. Bioresour. Technol. 2008, 99, 8873-8879.

3. Lacey, J.M.; Wilmore, D.W. Is glutamine a conditionally essential amino acid? Nutr. Rev. 1990, 48, 297-309.

4. Rombouts, I.; Lamberts, L.; Celus, I.; Lagrain, B.; Brijs, K.; Delcour, J.A. Wheat gluten amino acid composition analysis by high-performance anion-exchange chromatography with integrated pulsed amperometric detection. J. Chromat. 2009, 1216, 5557-5562. 
5. Harstad, O.M.; Prestlǿkken, E. Rumen degradability and intestinal indigestibility of individual amino acids in corn gluten meal, canola meal and fish meal determined in situ. Anim. Feed 2001, 94, 127-135.

6. Han, B.Z.; Rombouts, F.M.; Robert Nout, M.J. Amino acid profiles of sufu, a Chinese fermented soybean food. J. Food Comp. Anal. 2004, 17, 689-698.

7. Sacks, G.S. Effect of glutamine-supplemented parenteral nutrition on mortality in critically ill patients. Nutr. Clin. Pract. 2011, 26, 44-47.

8. Prabhu, R.; Thomas, S.; Balasubramanian, K.A. Oral glutamine attenuates surgical manipulation-induced alterations in the intestinal brush border membrane. J. Surg. Res. 2003, 115, 148-156.

9. Rogero, M.M.; Tirapegui, J.; Pedrosa, R.G.; Castro, I.A.D.; Oliveira Pires, I.S.D. Effect of alanyl-glutamine supplementation on plasma and tissue glutamine concentrations in rats submitted to exhaustive exercise. Nutrition 2006, 22, 564-571.

10. Schneider, T.; Butzb, P.; Ludwig, H.; Tauscher, B. Pressure-induced formation of pyroglutamic acid from glutamine in neutral and alkaline solutions. LWT Food Sci. Technol. 2003, 36, 365-367.

11. Tanabe, S.; Watanabe, M.; Arai, S. Production of a high-glutamine oligopeptide fraction from gluten by enzymatic treatment and evaluation of its nutritional effect on the small intestine of rats. J. Food Biochem. 1992, 16, 235-248.

12. Wu, Z.P.; Chang, S.; Jin, Q.G. Research on the effects of glutamine and soybean peptide supplementation on the structure of kidney filtration barrier and component of urinary of over-training rats. J. Guangzhou Sport Univ. 2008, 28, 93-97, (in Chinese).

13. Peričin, D.; Radulović-Popović, L.J.; Vaštag, Ž.; Madarev-Popović, S.; Trivić, S. Enzymatic hydrolysis of protein isolate from hull-less pumpkin oil cake: Application of response surface methodology. Food Chem. 2009, 115, 753-757.

14. Lv, Y.; Guo, S.T.; Yang, B.C. Aggregation of hydrophobic soybean protein hydrolysates: Changes in molecular weight distribution during storage. LWT Food Sci. Technol. 2009, 42, 914-917.

15. Tavares, T.G.; Contreras, M.M.; Amorim, M.; Martín-Álvarez, P.J.; Pintado, M.E.; Recio, I.; Malcata, F.X. Optimisation, by response surface methodology, of degree of hydrolysis and antioxidant and ACE-inhibitory activities of whey protein ydrolysates obtained with cardoon extract. Int. Dairy J. 2011, 21, 926-933.

16. Contreras, M.D.M.; Hernández-Ledesma, B.; Amigo, L.; Martín-Álvarez, P.J. Production of antioxidant hydrolyzates from a whey protein concentrate with thermolysin: Optimization by response surface methodology. LWT Food Sci. Technol. 2011, 44, 9-15.

17. Murthy, M.; Swaminathan, T.; Rakshit, S.K.; Kosugi, Y. Statistical optimization of lipase catalyzed hydrolysis of methyloleate by response surface methodology. Bioprocess. Eng. 2000, 22, 35-39.

18. Xie, Y.L.; Ma, C.Y.; Wang, J.S. Optimization of the trypsinase hydrolysis condition of glutamine peptides from defatted soybean meal by response surface analysis. J. Henan Univ. Technol. (Nat. Sci. Ed.) 2009, 30, 25-28, (in Chinese).

19. Chen, L.; Chen, J.S.; Ren, J.Y.; Zhao, M.M. Modifications of soy protein isolates using combined extrusion pretreatment and controlled enzymatic hydrolysis for improved emulsifying properties.

Food Hydroc. 2011, 25, 887-897. 
20. Guo, Y.X.; Pan, D.D.; Tanokura, M. Optimisation of hydrolysis conditions for the production of the angiotensin-I converting enzyme (ACE) inhibitory peptides from whey protein using response surface methodology. Food Chem. 2009, 114, 328-333.

21. Adler-Nissen, J. Limited enzymic degradation of proteins: A new approach in the industrial application of hydrolysates. J. Chem. Tech. 1982, 32, 138-156.

22. Marlene, T.; Don, E.O. Quantification of glutamine in proteins and peptides using enzymatic hydrolysis and reverse-phase high-performance liquid chromatography. Anal. Chem. 1999, 269, 143-148.

23. Dong, S.Y.; Zeng, M.Y.; Wang, D.F.; Liu, Z.Y.; Zhao, Y.H.; Yang, H.C. Antioxidant and biochemical properties of protein hydrolysates prepared from Silver carp (Hypophthalmichthys molitrix). Food Chem. 2008, 107, 1485-1493.

(C) 2012 by the authors; licensee MDPI, Basel, Switzerland. This article is an open access article distributed under the terms and conditions of the Creative Commons Attribution license (http://creativecommons.org/licenses/by/3.0/). 